\title{
ぢふてり一毒素並二ふおろもわくちんノ注射 ガ海猽補體二及ボス影響二就テ
}

\author{
目黑研究所 (所長 目黑清三郎博士) \\ 山 村 浩 \\ Hiroshi Yamamura
}

（昭和 12 年 1 月 19 日受付

\section{【内 容 抄 錄】}

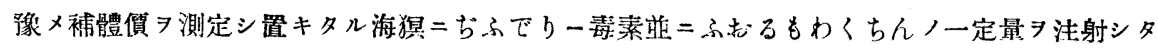

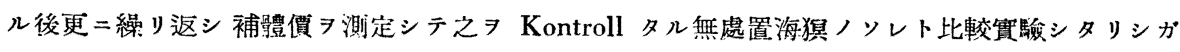
何レモ著シキ影響ヨ被ラザルョ知リタリ。

目

緒 言

第 1 章. 實驗材料留二筫驗方法

第 1 節 實驗材料

第 1 項 實驗動物

第 2 項 溶血素

第 3 項 血球液

箩 2 節 實驗方法

\section{次}

第 1 項 注射及探血

第 2 項 補體價 八测定法

管 2 章 實驗成績

䖝 3 章 總括前 $=$ 考按

第 4 章 結 諭

主要文献

\section{緒言}

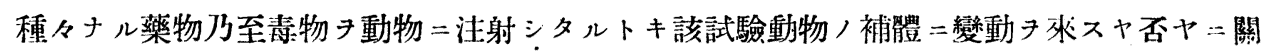
スル幾多ノ實驗成績八慨二諸學者ニヨリテ報告七ラレタルトコロナリ．

Ehrlich, Morgenroth.八燐油/皮下及ビ靜胍內注射ガ補體/著シキ减少乃至消失き招來 スルノ事實キ述べ，又 Pinner 八あとろびん及ビあどれなりん，注射二ヨル補體ノ减少認

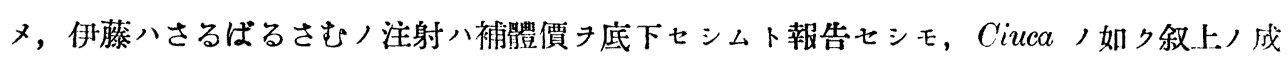

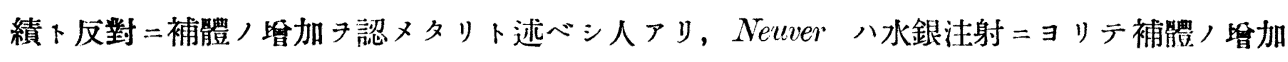

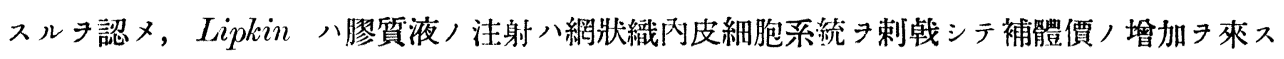
コトアルモ或ハ其ノ減少キ招クコトアリテ成績不定ナリト言へリ。

其他多數，實驗報告アリテ之ガ枚擧二遑アラズト踓モ之キ總括的二觀ズル時ハ, 注射セシ 藥品乃至毒物, 種類ニヨリテ補體價 =及ボス影響/異ナルハ旸論, 同一藥品或八毒物，注射

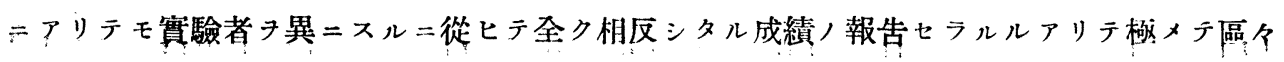


タルもノアリ.

余モ亦多年目黑博士指導,下ニぢふてり一毒素, 研究=没頭セル站チ場ヨリシテ，ぢふて

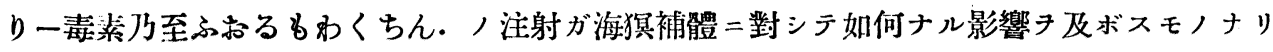
ヤ二就キテノ實驗キ行ヒタルキ以キ茲二簡單ナル成績, 報告キ行ハント欲スルモノナリ.

\section{第 I 章 實驗材料並二實驗方法}

\section{第 I 節 實 驗 材 料}

\section{第 I 項 實 驗 動 物}

海猽八體重 $300-350 \mathrm{~g}$ 程度ニテ健康狀態良好ナルモノフ探用ス. 15 頭ノ海猽 33 群二分于 各 5 頭宛丹以テ 1 群 形成シタル上，同一めぢちむ:飼養シテ可及的外的條件ノ一致キ期シタ リ。而シテ各群ノ筫驗二對スル割當ハ次ノ如シ.

第 1 群 ぢふてりー素素注射

第 2 群 ぢふてりーふおるもわくちん注射

第 3 群 對照(無處置)

\section{第 2 項 溶 血 素}

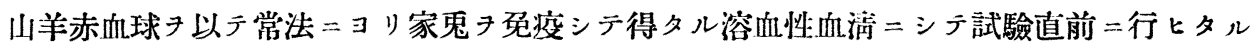

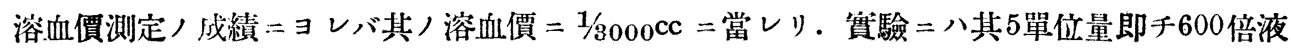
ノ0.5cc宛き使用スルコトトセリ。

第 3 項 血 球 液

山羊ノ赤血球キ探取後3--4回隇菌生理的食監水二テ洗湺シタル後, 更二生理的食鹽水

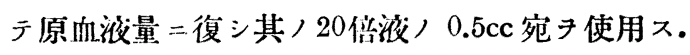

\section{第 2 節 實 驗方 法}

\section{第 | 項 注射及ビ探血}

先ソ第 1 群, 第 2 群, 第 3 群, 何レモ一齊二採血ノ上補體價 タ测定ス. 滿5日ノ後, 第 1 群 ニハぢふてりー毒素） 1DLM（DLM=1/200cc） タ，第2 群ニハふおるもわくちん，5cc タ 何レモ皮下注射シ，(第 3 群八對照トシテ無處置トス). 以後 2 日目，4日目，，2回二亘りテ前 記 3 群ノ海猽ノ採血キ行七補體價タ檢セリ。

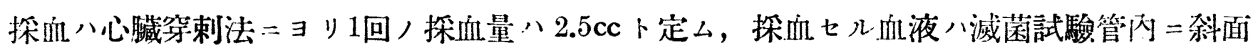

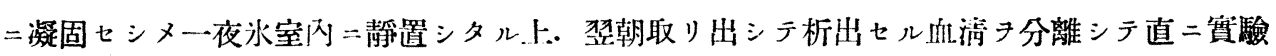
二供セリ。 
(462)

\section{第 2 項 補體價測定法}

補體價 ノ測定ハ次二表云セル法二低ル。

第 1 表

\begin{tabular}{|c|c|c|c|c|c|c|c|c|c|c|c|c|c|}
\hline 試驗管番號 & 1 & 2 & 3 & 4 & 5 & 6 & 7 & 8 & 9 & 10 & 11 & 12 & 13 \\
\hline 海晖補 體 $\begin{array}{r}10 \times \\
100 \times\end{array}$ & 0.7 & 0.6 & 0.5 & 0.4 & 0.3 & 0.2 & 0.1 & 0.8 & 0.6 & 0.4 & $\begin{array}{c}1.0 \\
\end{array}$ & 1, & 1 \\
\hline 生 理 的食臨 水 & 0.3 & 0.4 & 0.5 & 0.6 & 0.7 & 0.8 & 0.9 & 0.2 & 0.4 & 0.6 & 0.5 & 1.0 & 1.5 \\
\hline 溶 血 美（5 單位） & 0.5 & "1 & "1 & " & " & "1 & 11 & " & $"$ & $" 1$ & $\angle$ & 0.5 & 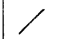 \\
\hline 血球 液 $(200 \times)$ & 0.5 & " & " & " & " & " & " & " & " & " & 0.5 & 0.5 & 0.5 \\
\hline & \multicolumn{13}{|c|}{$37^{\circ} \mathrm{C}$ - 2 時間 } \\
\hline 一例, 珹 績 & HH & H & $H$ & $H$ & H & $H$ & + & + & + & & - & - & - \\
\hline
\end{tabular}

H 八完全溶血

＋八殆ンド完全溶血

+ 八少シク溶血

一八溶血习認メズ

補體賈ハ完全溶血 來セル最少補體量キ以テ現ハスモノナルガ故二上記ノ 1 例＝於テハ 0.0

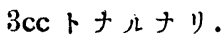

\section{第 2 章 實 驗 成 績}

豫メ正常補體價キ測定シタル海猽 15 頭キ 3 群二分チ，第 1 群 =ハ DLM $=1 / 200 \mathrm{cc}$ ナル新鮮ぢふ てりー毒養ノ $1 \mathrm{DLM}$ 第2群ニハら゙ふてりーふおるもわくちん $5 \mathrm{cc}$ 宛习注射シ，何レモ注射 後滿 2 日目, 4日目=該試驗動物ノ補體價 キ測定シテ之ヨ對照トシテ無處置ニオケル第 3 群海 猽ノソレト對比實驗スルコトトシ。前記ノ補體價測定法＝從ヒテ逐次實驗キ進メタリシガ,

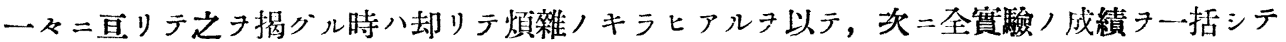
之ア表示シー一目睹然タラシメント欲シタリ・

\begin{tabular}{|c|c|c|c|c|c|c|c|c|}
\hline & 海 & $\begin{array}{l}\text { 腪 } \\
\text { 號 }\end{array}$ & 體重 & $\begin{array}{l}\text { 洼射 } 5 \text { 日前 } \\
\text { 補 } h_{\text {體 }}\end{array}$ & & 涐射後 & 清射後 & 生 死 \\
\hline 第 & & & 320 & 0.02 & \multirow{5}{*}{$\begin{array}{c}\text { ら゙ふてり一毒素 } \\
\text { 1DLM淮射 }\end{array}$} & 0.04 & 0.04 & 6 日目死 \\
\hline & & & 300 & 0.03 & & 0.05 & 0.05 & 5 日目死 \\
\hline \multirow[t]{2}{*}{1} & & & 330 & 0.03 & & 0.06 & 0.06 & 5 日目死 \\
\hline & & & 315 & 0.02 & & 0.04 & 0.05 & 6 日目死 \\
\hline 群 & & & 330 & 0.03 & & 0.05 & 0.06 & 7 日目死 \\
\hline
\end{tabular}




\begin{tabular}{|c|c|c|c|c|c|c|c|}
\hline & $\begin{array}{ll}\text { 海 犋 } \\
\text { 虒 }\end{array}$ & 體 重 & $\begin{array}{l}\text { 注射 } 5 \text { 日前 } \\
\text { 補 骬 價 }\end{array}$ & & $\begin{array}{l}\text { 婊射 後 } \\
2 \text { 目 }\end{array}$ & 洼射後 & 生 死 \\
\hline \multirow{2}{*}{ 第 } & 6 & 300 & 0.03 & \multirow{5}{*}{$\mid \begin{array}{c}\text { ふおるもわくちん } \\
5 \mathrm{cc} \text { 注射 }\end{array}$} & 0.03 & 0.04 & 生 \\
\hline & 7 & 350 & 0.02 & & 0.04 & 0.33 & "I \\
\hline 2 & 8 & 340 & 0.02 & & 0.04 & 0.04 & " \\
\hline \multirow{3}{*}{ 群 } & 9 & 320 & 0.03 & & 0.05 & 0.05 & " \\
\hline & 10 & 333 & 0.04 & & 0.06 & 0.06 & " \\
\hline & & & & 以下注射七 & & & \\
\hline \multirow{2}{*}{ 第 } & 11 & 315 & 0.02 & \multirow{5}{*}{ 對 } & 0.04 & 0.04 & 生 \\
\hline & 12 & 320 & 0.03 & & 0.65 & 0.95 & " \\
\hline 3 & 13 & 320 & 0.03 & & 0.03 & 0.04 & " \\
\hline \multirow[b]{2}{*}{ 群 } & 14 & 330 & 0.02 & & 0.03 & 0.04 & 11. \\
\hline & 15 & 340 & 0.02 & & 0.04 & 0.05 & " \\
\hline
\end{tabular}

以上䐝驗成績习表示七シ如ク，ぢふてり一毒素並ニふおるもわくちんノ注射八海猽補體 = 對シテ著シキ影響キ及ボサザルモノノ如ク觀察セラル。

即チぢふてりー毒素1DLM ォ皮下注射セシ第 1 群海猽＝於テハ注射後滿2日目二於テ補體

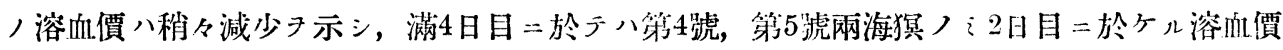
ヨリモ更二幾分ノ减少丹來シタルモ他ノ3頭ノモノ八2日目二於ケル補體卜全ク同一/溶血價 ヨ示セリ. 本成績ノミ゙徴シテ考擦スル時ハ一見毒素ノ注射ニヨリテ補體ノ减少テ招來セシ

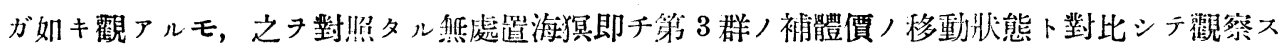
ル時八其處二何等相違, 見ルベキモノナク補體ノ移動减弱狀况、全ク同一ノ經路キ辿レルキ 知り得ベシ。筫ニぢ毒素 1 DLM 注射後4日目卜言へバ海猽ノ中毒症斨八正二其，頂點二達七 几時ニシテ、第2號第 3 號海猽ノ如キ八殆ンド死 $=$ 瀕セ儿時期ナリトス. 若シモ毒素ノ注射二

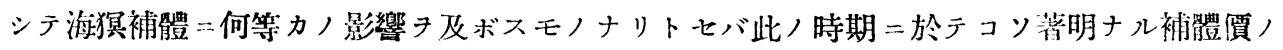

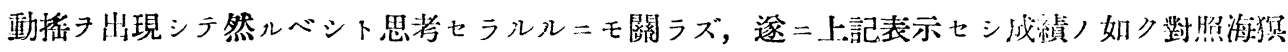
ト對此シテ何等ノ相違きモ認ムルコト能ハザリキ。

ふおるもわくちん $5 \mathrm{cc}$ チ皮下注射七シ第2 2 群海猽二於テモ亦注射後 2 日目二八補體賈/稍々 减少セルタ認ムルモ，4日目ニ於ケル實驗成續八2日目ニ於ケル補體價卜殆ンド同一ニシテ最

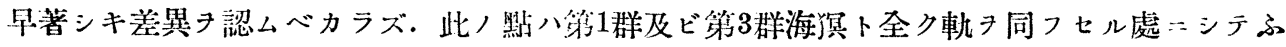
おるもかくちんノ注射モ亦海猽補體二對シテハ著シキ影響ヨ及ボサザルモノトシテ美シ支へ ナカラント信ズルモノリリ。

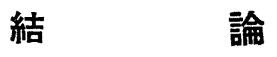

1. ぢふてりー毒素ヨ海猽皮下二注射スルモ其補體ニ對シテハ著シキ影響タ及ボサザルモ 
ノト認ム

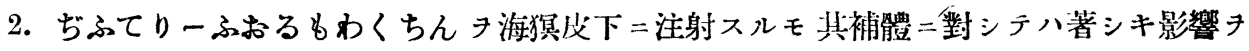
及ボサザルモノト認ム。

擱筆二際シ御鞭撻御指導卜御懇篤ナル御校閱ノ勞タ基つセシ恩師目黑博士二對シテ滿焢 謝意き表ス.

\section{主 要 文 献}

1) W. Kalle, R Kraus und P. Uhlenhuth.: Handbuch Jphaihog.Mikroorg. Band 12

2) H. Schmidt : Fartsch. d. Serologie. 3) Ciuca: cit. u. Sachs u KIopstock.

4) Pimer : Beitr. Z. klinik. d Tuberkulasl. (1921). 5) Lipkin : Ref. c. f. Bact.

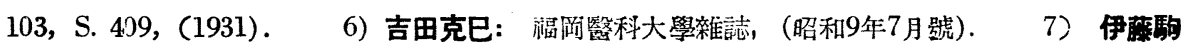

夫: 岡山醫學會雜誌, 第41年, 第5號. 3 8) Ehrlich, u. Morjenraih. : Berl. Klin.

Wschrif. (1899). 